International Journal of Agriculture, Environment and Bioresearch

Vol. 06, No. 04; 2021

ISSN: $2456-8643$

\title{
EFFECT OF METHANOL AND AQUEOUS EXTRACT OF PRUNELLA VULGARISA ON BACTERIA ISOLATED FROM WOUND INFECTION
}

\author{
Anmar Saadi Aboud \\ Mustansiryah University, College of Sciences, Department of Biology. Baghdad, Iraq \\ https://doi.org/10.35410/IJAEB.2021.5658
}

\begin{abstract}
This study provides a scientific information about the aqueous and methanol extracts of Prunella vulgarisa based on its antimicrobial potential against gram positive and gram negative bacteria isolated from wound infection using the broth dilution and well diffusion method. Results of this study indicate the presence of many phytochemicals which have antimicrobial activity against broad spectrum of bacteria. The methanol extract of P. vulgarisa showed highest activity than aqueous ones. The minimum inhibitory concentration (MIC) of the aqueous extract on the tested organisms was $25-100 \mathrm{mg} / \mathrm{ml}$ while in the methanol extract ranged between $25-50 \mathrm{mg} / \mathrm{ml}$ on the tested organisms and the minimum bacterial concentration (MBC) of the aqueous extract was 25$100 \mathrm{mg} / \mathrm{ml}$ while the methanol extract ranged between $25-100 \mathrm{mg} / \mathrm{ml}$. The highest activity of methanol extract demonstrated at 100 Co, 121 Co against S.aureus, K.spp, A.hydrophila, and S.marcescens, while there was low activity against S.dysenteria and E.coli. The activity of plant extract increased at acidic pH5-3 whearus, there are slightly increased of plant extract at alkaline $\mathrm{pH}$ 8. P. vulgarisa contained. essential element ( $\mathrm{Pb}, \mathrm{Na}, \mathrm{K}, \mathrm{Ca}, \mathrm{Fe}, \mathrm{Zn}, \mathrm{P}, \mathrm{Mn}, \mathrm{Co}$ and $\mathrm{Cu})$ at different concertation.
\end{abstract}

Keywords: Plant extract, Prunella vulgarisa, Antimicrobial activity.

\section{INTRODUCTION}

It is well known that infectious diseases are responsible for a high proportion of health problems, especially in developing countries. The situation has created immense clinical problems for infectious disease treatment. More scientists are in search for new antimicrobial substances derived from plants. Historically, plants provide us with a good source of anti-infective agents [1]. However, an emerging problem associated with misuse of antibiotic therapy is the worldwide emergence of higher level tolerance of target organisms against available broad spectrum antibiotics. As a result, and in the light of the rapid spread of multidrug resistance, the development of new antimicrobial or antipathogenic agents that act upon new microbial targets has become a very pressing priority [2]. In the traditional systems of medicine, plants are used in the form of crude extracts, infusions and powders to treat common infections without scientific evidence of efficacy [3]. Plants are rich in a variety of secondary metabolites such as tannins, terpenoids, alkaloids, flavonoids, phenols, steroids, glycosides and volatile oils [4]. It is necessary to identify the phytochemical components of local medicinal plants usually employed by herbalists in the treatment of diseases, especially now that there are proposals on the 
Vol. 06, No. 04; 2021

ISSN: $2456-8643$

integration of traditional medicine in health care programme in world. In addition, investigations into antimicrobial activities of local medicinal plants will expose the plants as potential sources of therapeutic agents [5]. Prunella vulgaris, a perennial plant from Labiatae family, is widely distributed in Asia, Europe. It is traditionally used for eye pain, inflammation, headache, dizziness, sore throat and wound healing [6]. P. vulgaris is known as selfheal; contains several active components, including oleanolic acid, betulinic acid, ursolic acid, flavonoids and rosmarinic acid [7]. Some pharmacological activities such as the immunmodulatory effect [8], anti-viral activity against HSV-1, HSV-2, HIV, antioxidant activity] and anti hyperglycemic action were confirmed. In spite of its traditional uses as an antiseptic agent for treatment of wounds and sore throat, there are a few literatures on its antimicrobial activity. The antimicrobial activity of P. vulgaris methanol extract against Staphylococcus aureus and Enterococcus faecalis was confirmed [9]. The P. vulgaris were used in oral preparations for control of gingivitis. In China, the aqueous extract from fruit spikes were used in typical dose of 9-15 g per day for different ailments [10].

The aim of this study was to investigate the inhibitory effect of P. vulgaris secondary metabolites on bacteria isolated from wound infections .

\section{MATERIALS AND METHODS}

\section{Collection of plant samples:}

The medicinal plant in for the experiment was identified according to various literatures, and including other pertinent taxonomic literature.. The plant was washed thoroughly and chopped into small pieces shade dried and grinded into powdered form.

\section{Test microorganisms:}

Bacterial species Shigella dysenteriae; Aeromonas hydrophila; Escherichia coli; Klebsiella spp;Serratia marcescens and Staphylococcus aureus were all obtained from Al-Kindi Hospital.

\section{Culture medium and inoculum:}

The stock cultures of microorganisms used in this study were maintained on Plate Count Agar slants at $+4{ }^{\circ} \mathrm{C}$. Cell suspansions were prepared by inoculation of each bacteria into $10 \mathrm{ml}$ of Nutrient broth. Incubation was performed at $37{ }^{\circ} \mathrm{C}$ for $24 \mathrm{~h}$. On the next day Mueller-Hinton Agar (MHA) was prepared and cooled to $45{ }^{\circ} \mathrm{C}$. Bacterial suspension was added into MHA to give a final concentration of $107 \mathrm{bacteria} / \mathrm{ml}$ and plated out.

\section{Phytochemical screening:}

The plant extracts were screened for phytochemical constituents using standard procedures of analysis. These were done at College of Science / Department of Biology / Al-Mustansiryah University. The tests were carried out by using a stock concentration of $500 \mathrm{mg} / \mathrm{ml}$ prepared by dissolving $1 \mathrm{gm}$ of the methanol extract (MTE) and aquatic extract into $2 \mathrm{ml}$ of distilled water, [11].

\section{Antibacterial activity:}

The plate-hole diffusion assay as described by [12] was used to determine the growth inhibition of bacteria by the plant extract. The isolated bacteria from burn infection were obtained. Nutrient agar was prepared and $25 \mathrm{ml}$ each was poured into sterile petri dish. This was allowed to solidify and dry. Using a sterile cock-borer of $9 \mathrm{~mm}$ diameter three equi-distant holes per plate were made in the set agar and were inoculated with $0.5 \mathrm{ml}$ over night suspension of the bacteria. Thereafter, the wells (holes) were filled with the extract solution volume $100 \mu \mathrm{l}$ at varying 
Vol. 06, No. 04; 2021

ISSN: $2456-8643$

concentrations of $500 \mathrm{mg} / \mathrm{ml}, 400 \mathrm{mg} / \mathrm{ml}$ and $300 \mathrm{mg} / \mathrm{ml}$ respectively. This was done in triplicate and the plates were incubated at $37^{\circ} \mathrm{C}$ for 18 hours. The antibacterial activities were observed and measured using a transparent meter rule and recorded if the zone of inhibition was $10 \mathrm{~mm}$ [13].

\section{Minimum Inhibitory Concentration (MIC):}

Reuben et al., method [14] was employed. In this method, the broth dilution technique was utilized where the plant extract was prepared to the highest concentration of $500 \mathrm{mg} / \mathrm{ml}$ (stock concentration) in sterile distilled water and serially diluted (two-fold) into a working concentration ranging from $0.780 \mathrm{mg} / \mathrm{ml}$ to $200 \mathrm{mg} / \mathrm{ml}$ using nutrient broth and later inoculated with $0.2 \mathrm{ml}$ suspension of the test organisms. After 18 hours of incubation at $37^{\circ} \mathrm{C}$, the test tubes were observed for turbidity. The least concentration where no turbidity was observed was determined and noted as the minimum inhibitory concentration (MIC) value.

Minimum Bacterial Concentration (MBC):

This was determined from the broth dilution resulting from the MIC tubes by sub culturing to antimicrobial free agar as described by Usman et al., [15]. In this technique, the contents of the test tubes resulting from MIC was streaked using a sterile wire loop on agar plate free of bacteria and incubated at $37{ }^{\circ} \mathrm{C}$ for 18 hours. The lowest concentration of the extract which showed no bacterial growth was noted and recorded as the MBC.

The effect of heat and $\mathrm{pH}$ on the antimicrobial activity of medicinal plant extract:

The samples of plant extract (one vial of $100 \mathrm{ml}$ ) were provided to determine the effect of heat on it, test samples were heated $45^{\circ} \mathrm{C}, 70{ }^{\circ} \mathrm{C}, 100{ }^{\circ} \mathrm{C}$ and $121{ }^{\circ} \mathrm{C}$ for $15 \mathrm{~min}$. [16]. To determine the effect of $\mathrm{pH}$, extracts were treated at $\mathrm{pH}$ ranges of 3 to 8 using $1 \mathrm{~N} \mathrm{HCl}$ and $1 \mathrm{~N} \mathrm{NaOH}$ solutions respectively in series of test tubes for $1 \mathrm{~h}$ and then tested for antibacterial activity [17].

\section{Determination of Essential elements:}

This experiment was carried out in the central laboratory, College of Science / Department of Biology / University of Baghdad. Three grams of dried plant were taken and mixed with $8 \mathrm{ml}$ of concentrated $\mathrm{H} 2 \mathrm{SO} 4(98 \%)$ and $2 \mathrm{ml}$ of $\mathrm{HClO} 3(60 \%)$ in aconical flask for 24 hours which covered by watch class. Then this mixture was left for 6 hours on the sand bath at $80 \mathrm{C}^{\circ}$, until the digestion material converted into white powder. Then $8 \mathrm{ml}$ of deionized water were added to this powder and the trace elements were determined by flame atomic absorption spectrophotometer, [18].

\section{RESULTS AND DISCUSSION}

The results of phytochemical screening for P. vulgarisa are shown in Table1 which reveals the presence of Alkaloids, Phenol,Cardiac glycosides, Flavonoids, Terpenes, Tanins, Ratenges, Coumarines, and Essensial oil which were secondary metabolites have been used in traditional Chinese medicine for its antibacterial, antioxidant and anti-inflammatary activities [19,20]. In other research phytocemical constituents in the roots of Prunella was identified with the aid of high-preformance liquid chromatography and liquid chromatography mass spectrometry and by comparsion with authentic standards [21]. Controlled studies indicate the great potential of phytochemicals to be the richest reservoir of new and novel therapeutics [22]. Although the antimicrobial activities of plant extracts are beyond doubt, in many instances their exact mechanism of antimicrobial functionality is not well understood [23, 24]. 
International Journal of Agriculture, Environment and Bioresearch

Vol. 06, No. 04; 2021

ISSN: $2456-8643$

Table (1) .Phytochemical screening of Methanol, Hot and Cold water extract of P. vulgarisa.

\begin{tabular}{|c|c|c|c|c|}
\hline Number & Constituents & Methanol extract & $\begin{array}{c}\text { Hot water } \\
\text { extract }\end{array}$ & $\begin{array}{c}\text { Cold water } \\
\text { extract }\end{array}$ \\
\hline \multirow[t]{2}{*}{1} & Alkaloids & & & \\
\hline & $\begin{array}{l}\text { i.Dragendorff's test } \\
\text { ii.Meyer's test }\end{array}$ & + & + & + \\
\hline \multirow[t]{2}{*}{2} & Pheno I & & & \\
\hline & & + & + & + \\
\hline \multirow[t]{2}{*}{3} & Cardiac glycosides & & & \\
\hline & Killer-killanis test & + & + & + \\
\hline \multirow[t]{2}{*}{4} & Flavonoids & & & \\
\hline & $\begin{array}{l}\text { i.Shinoda's test } \\
\text { ii. } \mathrm{FeCl}_{3} \text { test }\end{array}$ & + & + & + \\
\hline \multirow[t]{2}{*}{5} & Saponins & & & \\
\hline & Frothing test & - & - & - \\
\hline \multirow[t]{2}{*}{6} & Terpenes & & & \\
\hline & Salkowski test & + & + & + \\
\hline \multirow[t]{2}{*}{7} & Steroids & & & \\
\hline & Libarman-Burchard's test & - & - & - \\
\hline \multirow[t]{2}{*}{8} & Tanins & & & \\
\hline & $\begin{array}{l}\text { i. } \mathrm{FeCl}_{3} \text { test } \\
\text { ii.Lead acetate test }\end{array}$ & + & + & + \\
\hline \multirow[t]{2}{*}{9} & Ratenges & & & \\
\hline & & + & + & + \\
\hline \multirow[t]{2}{*}{10} & Coumarines & & & \\
\hline & & + & + & + \\
\hline \multirow[t]{2}{*}{11} & Essensial oil & & & \\
\hline & & + & + & + \\
\hline
\end{tabular}

The results of antibacterial activity of plant extract against test organism are list in Table2. In this study a positive correlation was found between concentration of test plant extract and the inhibition zone of pathogenic isolates. As is shown, the methanol extract of P. vulgarisa was more effective than two aqueous extract (hot and cold) for the same plant,and the hot aqueous extract of plant was more effective than cold extract. S.aureus showed zone of inhibition for aqueous and methanol extract. while all gram negative bacteria; K.spp, A..hydrophila,S.marcesence, S.dysenteriae and E.coli exhibit variation in zone of inhibition 
respectively. The results of this study in agreed with other researches which showed that plant extracts with well documented antimicrobial activities could possess antipathogenic as well as antivirulent activities, which may not be linked to the growth and inhibition of the microorganism [25]. Al-Fatimi, et al. [26] studied In vitro antimicrobial activity of crude dichloromethane, methanol and aqueous extracts of medicinal plants in Yemeni ethnomedicine and showed good activity against gram positive and negative bacteria. Aysegul, et al. [27] reported that the hydro alcoholic extract of P. vulgarisa has an antioxidant activity and an antimicrobial effect on bacilli, escirichiae and staphylococci. The magnitude of activity varied in terms of the type and number of bacteria and fungi tested and the part of the plant extracted. In addition it is well established that the polarity of these extracts where in our case ethanol is highly polar which probably means getting different profiles in the activity if other extracts of different polarity were used [28].

Table (2) Antibacterial Activity of P. vulgarisa Extracts against Test Organisms.

\begin{tabular}{||l|c|c|c|c|c|c|c||}
\hline $\begin{array}{c}\text { Extract/concentration } \\
\text { Mg/ml }\end{array}$ & \multicolumn{7}{|c||}{ Zone of inhibition (mm) } \\
\hline & Cone. & K.spp & S.marcescens & A.hydrophila. & S.dysenteriae & E.coli & S.aureus \\
\hline \hline Methanol Extract of & 500 & 25 & 17 & 22 & 10 & 13 & 40 \\
$P$. vulgarisa & 400 & 22 & 15 & 20 & 9 & 11 & 35 \\
& 300 & 18 & 14 & 17 & 7 & 10 & 32 \\
\hline Hot aqueous Extract & 500 & 19 & 15 & 20 & 10 & 11 & 38 \\
of $P$. vulgarisa & 400 & 16 & 14 & 19 & 8 & 10 & 35 \\
& 300 & 15 & 12 & 17 & 7 & 8 & 30 \\
\hline Cold aqueous Extrac & 500 & 16 & 14 & 14 & 8 & 9 & 35 \\
of $P$. vulgarisa & 400 & 15 & 13 & 12 & 7 & 7 & 28 \\
& 300 & 13 & 13 & 10 & 7 & 6 & 20 \\
\hline Control (water) & - & - & - & - & - & - & - \\
\hline Control (Methanol) & - & - & - & - & - & - & - \\
\hline \hline
\end{tabular}

The minimum inhibition concentration (MIC) and minimum bactericidal concentration (MBC) results are shown in table 3 and 4, respectively. The highest MIC and MBC values is an indication that either the plant extracts are less effective on some bacteria or that the organism has the potential of developing antibiotic resistance, while the low MIC and MBC values for other bacteria is an indication to the efficacy of the plant extract. The result of this study was in agreement with other researches which showed antimicrobial activity of ethanol, methanol, ethyl acetate and water extract of P. vulgarisa by disc diffusion method, from this study it was found that P. vulgarisa revealed antimicrobial activity against some gram positive and gram negative bacteria, yeast, filamentous fungi and actinomycetes [29]. These MIC values for the different bacteria though relatively high, are definitely demonstrative of the potential clinical use [30]. The microorganisms were least sensitive to the aqueous crude extracts due to negligible 


\section{International Journal of Agriculture, Environment and Bioresearch}

Vol. 06, No. 04; 2021

ISSN: $2456-8643$

secondary metabolites in it [1]. Biswas, et al. [31] pointed out to the use of this extract in the treatment of wounds and Injuries in the traditional medicine of India.

Table (3) Minimum Inhibitory Concentration (MIC) values for Bacterial Isolates Against P. vulgarisa extracts.

\begin{tabular}{|c|c|c|c|c|c|c|c|c|c|c|c|c|c|c|c|c|c|c|c|c|c|c|c|c|c|c|c|}
\hline \multirow{3}{*}{$\begin{array}{c}\text { Bacterial } \\
\text { Isolates }\end{array}$} & \multicolumn{27}{|c|}{ Extract concentration $(\mathrm{mg} / \mathrm{ml})$} \\
\hline & \multicolumn{3}{|c|}{0.780} & \multicolumn{3}{|c|}{1.560} & \multicolumn{3}{|c|}{3.125} & \multicolumn{3}{|c|}{6.25} & \multicolumn{3}{|c|}{12.5} & \multicolumn{3}{|c|}{25} & \multicolumn{3}{|c|}{50} & \multicolumn{3}{|c|}{100} & \multicolumn{3}{|c|}{200} \\
\hline & $\mathbf{M}$ & $\mathbf{H}$ & C & $\mathbf{M}$ & $\mathbf{H}$ & C & $\mathbf{M}$ & $\mathbf{H}$ & C & $\mathbf{M}$ & H & $\mathrm{C}$ & $\mathbf{M}$ & $\mathbf{H}$ & C & $\mathbf{M}$ & $\mathbf{H}$ & C & $\mathbf{M}$ & $\mathbf{H}$ & C & $\mathbf{M}$ & $\mathbf{H}$ & C & $\mathbf{M}$ & $\mathbf{H}$ & C \\
\hline K.spp & - & - & - & - & - & - & - & - & - & - & - & - & - & - & - & - & - & - & - & - & - & I & I & + & I & I & + \\
\hline S.marcescens & - & - & - & - & - & - & - & - & - & - & - & - & - & - & - & - & - & - & - & - & - & - & - & - & I & I & + \\
\hline A.hydrophila & - & - & - & - & - & - & - & - & - & - & - & - & - & - & - & - & - & - & - & - & - & - & - & - & I & I & + \\
\hline S.dysenteriae & - & - & - & - & - & - & - & - & - & - & - & - & - & - & - & - & - & - & - & - & - & - & - & - & I & I & - \\
\hline E.coli & - & - & - & - & - & - & - & - & - & - & - & - & - & - & - & - & - & - & - & - & - & - & - & - & I & - & - \\
\hline S.aureus & - & - & - & - & - & - & - & - & - & - & - & - & - & - & - & I & - & - & + & I & I & I & + & + & + & + & + \\
\hline
\end{tabular}

$-=$ Resistance (growth of bacteria).

$+=$ Concentrations show no turbidity (inhibition of bacterial growth).

$\mathrm{I}=$ least concentration showing no turbidity (MIC).

$\mathrm{M}=$ Methanol extract.

$\mathrm{H}=$ Hot aqueous extract.

$\mathrm{C}=$ Cold aqueous extract.

Table (4) Minimum Bactericidal Concentration (MBC) values for Bacterial Isolates Against P. vulgarisa extracts.

\begin{tabular}{|c|c|c|c|c|c|c|c|c|c|c|c|c|c|c|c|c|c|c|c|c|c|c|c|c|c|c|c|}
\hline \multirow{3}{*}{$\begin{array}{c}\text { Bacteria } \\
\text { Isolates }\end{array}$} & \multicolumn{27}{|c|}{ Extract concentration $(\mathrm{mg} / \mathrm{ml})$} \\
\hline & \multicolumn{3}{|c|}{0.780} & \multicolumn{3}{|c|}{1.560} & \multicolumn{3}{|c|}{3.125} & \multicolumn{3}{|c|}{6.25} & \multicolumn{3}{|c|}{12.5} & \multicolumn{3}{|c|}{25} & \multicolumn{3}{|c|}{50} & \multicolumn{3}{|c|}{100} & \multicolumn{3}{|c|}{200} \\
\hline & $\mathbf{M}$ & H & $\mathrm{C}$ & $\mathbf{M}$ & $\mathbf{H}$ & C & $\mathbf{M}$ & $\mathbf{H}$ & $\mathrm{C}$ & $\mathbf{M}$ & H & $\mathrm{C}$ & $\mathbf{M}$ & $\mathbf{H}$ & $\mathrm{C}$ & $\mathbf{M}$ & $\mathbf{H}$ & $\mathrm{C}$ & $\mathbf{M}$ & $\mathbf{H}$ & $\mathrm{C}$ & $\mathbf{M}$ & $\mathbf{H}$ & $\mathrm{C}$ & $\mathbf{M}$ & H & C \\
\hline K.spp & - & - & - & - & - & - & - & - & - & - & - & - & - & - & - & - & - & - & $B$ & $B$ & $B$ & + & + & + & + & + & + \\
\hline S.marcescens & - & - & - & - & - & - & - & - & - & - & - & - & - & - & - & - & - & - & - & - & - & $B$ & B & $B$ & + & + & + \\
\hline A.hydrophila & - & - & - & - & - & - & - & - & - & - & - & - & - & - & - & - & - & - & B & + & + & $B$ & B & + & + & + & + \\
\hline S.dysenteriae & - & - & - & - & - & - & - & - & - & - & - & - & - & - & - & - & - & - & - & - & - & - & - & - & - & - & - \\
\hline E.coli & - & - & - & - & - & - & - & - & - & - & - & - & - & - & - & - & - & - & - & - & - & - & - & - & - & - & - \\
\hline S.aureus & - & - & - & - & - & - & - & - & - & - & - & - & - & - & - & - & $B$ & $B$ & $B$ & + & + & + & + & + & + & + & + \\
\hline
\end{tabular}


$-=$ Resistance (growth of bacteria).

$+=$ Concentrations show no turbidity (inhibition of bacterial growth).

$\mathrm{B}=$ Minimum Bactericidal (MBC).

$\mathrm{M}=$ Methanol extract.

$\mathrm{H}=$ Hot aqueous extract.

$\mathrm{C}=$ Cold aqueous extract.

Results of the effect of temperature on the plant extracts showed that various temperatures; 45 $\mathrm{oC}, 70 \mathrm{oC}, 100$ Controllability and $121 \mathrm{oC}$ had various effects on the antimicrobial activity of the extracts (fig. 1,2,3) The highest activity of methanol extract at $100 \mathrm{Co}, 121 \mathrm{Co}$ against S.aureus, K.spp., A..hydrophila, and S.marcesencs respectively; while there was low activity against, S.dyesnteria and E.coli (no zone of inhibition). Whereas aqueous extract of P. vulgarisa revealed low activity than methanol extract and hot aqueous extract are more effective than cold aqueous extract.

Result of the effect of $\mathrm{pH}$ on the plant extract showed that plant extract was action in $\mathrm{pH}$ between (6-7), but the activity of plant extracts increased at acidic $\mathrm{pH}(5-3)$, i.e. increased in zone of inhibition of isolates at acidic $\mathrm{pH}$. While at $\mathrm{pH} 8$ there was slightly increase in activity.The methanol extract was more effective than hot and cold aqueous extract as shown in (Fig. 4,5,6,). Suleyman and Huseyin. [32] showed that P. vulgarisa generally grow on loam and clayey-loam, neutral to slightly alkaline soils and the activity of phytoconstiuents of this plant increased in the presence of acidic medium has earlier been reported. The treatment of plant with high temperature could commence to release simple sugars that could be readily utilized in protein synthesis. Release of hormones such as auxins and ethylene, which could increase nucleic acid metabolism and protein synthesis [33].

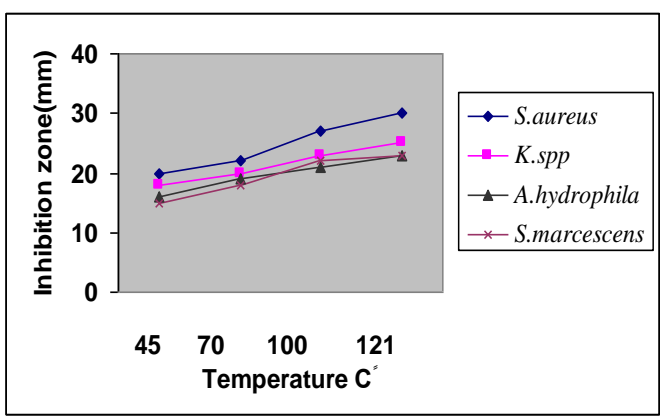

Fig. (1) Effects of temperature on antimicrobial activity of Methanol extract P. vulgarisa. 


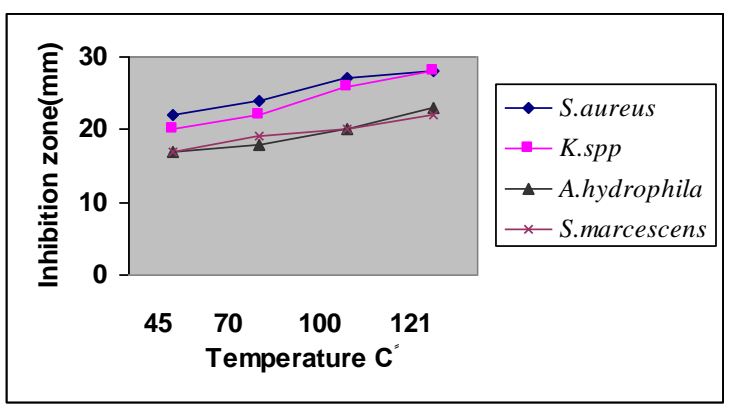

Fig. (2) Effect of temperature on antimicrobial activity of Hot aqueous extract P. vulgarisa.

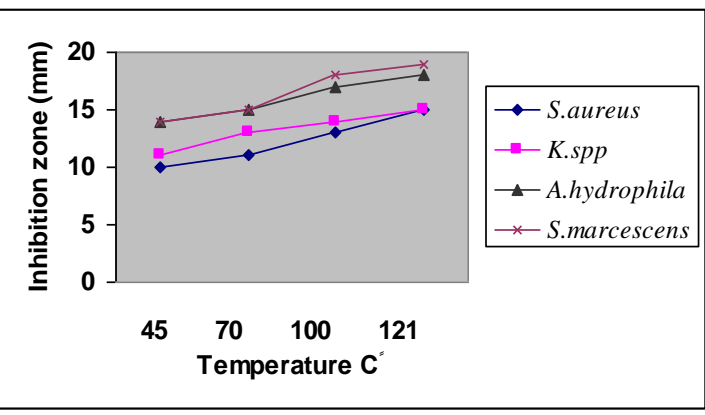

Fig. (3) Effect of temperature on antimicrobial activity of Cold aqueous extract P. vulgarisa.

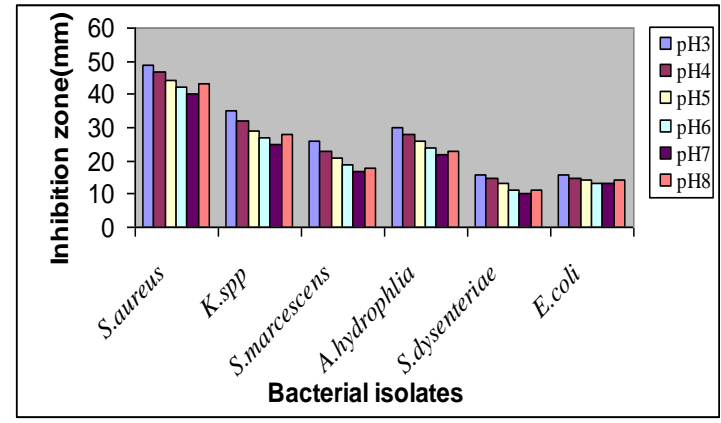

Fig. (4) Effects of $\mathrm{pH}$ on antimicrobial activity of Methanol extract P. vulgarisa.

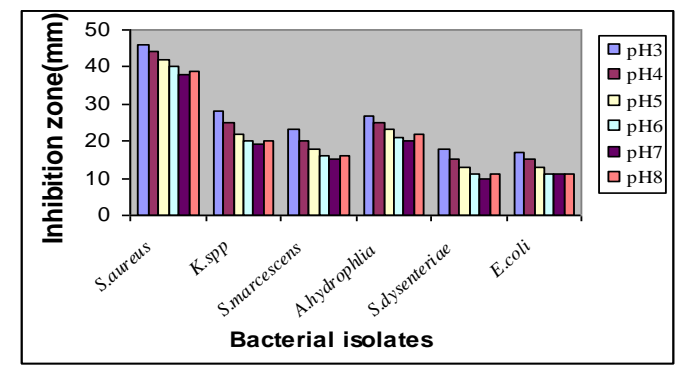

Fig.(5) Effect of $\mathrm{pH}$ on antimicrobial activity of Hot aqueous extract P. vulgarisa. 


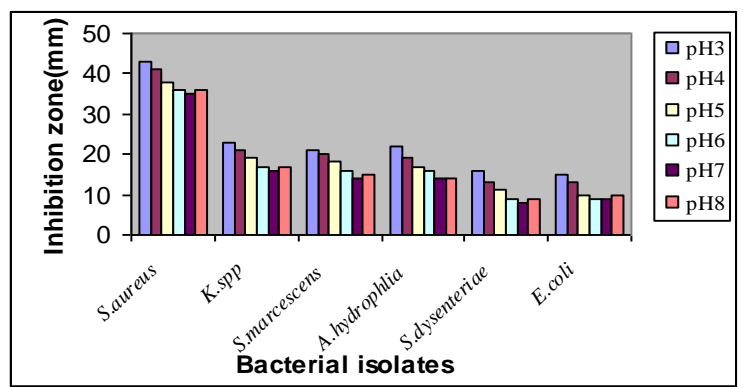

Fig.(6) Effect of $\mathrm{pH}$ on antimicrobial activity of Cold aqueous extract P. vulgarisa.

The results of essential elements determination ( $\mathrm{Pb}, \mathrm{Na}, \mathrm{K}, \mathrm{Ca}, \mathrm{Fe}, \mathrm{Zn}, \mathrm{P}, \mathrm{Mn}, \mathrm{Co}$, and $\mathrm{Cu}$ ) in $\mathrm{P}$. vulgarisa (table5) releavel the prescence of these elements at different concentration, these results are in agreement with the results of Suleyman and Huseyin. [33]who showed higer concentration of $\mathrm{Na}, \mathrm{Mn}, \mathrm{Zn}$, and $\mathrm{K}$ in $\mathrm{P}$. vulgarisa whereas $\mathrm{N}, \mathrm{P}$, and $\mathrm{Ca}$ were at lower concentration

Table (5) Essential elements concentration of $P$. vulgarisa.

\begin{tabular}{|c|c|c|}
\hline Elements & Concentration & P. vulgarisa \\
\hline \hline $\mathrm{Pb}$ & $\mathrm{ppm}$ & 0.3 \\
\hline $\mathrm{Na}$ & $\mathrm{ppm}$ & 613 \\
\hline $\mathrm{K}$ & $\%$ & 1.8 \\
\hline $\mathrm{Ca}$ & $\%$ & 0.85 \\
\hline $\mathrm{Fe}$ & $\mathrm{ppm}$ & 620 \\
\hline $\mathrm{Zn}$ & $\mathrm{ppm}$ & 94.2 \\
\hline $\mathrm{P}$ & $\%$ & 0.21 \\
\hline $\mathrm{Mn}$ & $\mathrm{ppm}$ & 6.4 \\
\hline $\mathrm{Co}$ & $\mathrm{ppm}$ & 1.9 \\
\hline $\mathrm{Cu}$ & $\mathrm{ppm}$ & 5.2 \\
\hline
\end{tabular}

\section{CONCLUSION}




\section{International Journal of Agriculture, Environment and Bioresearch}

Vol. 06, No. 04; 2021

ISSN: $2456-8643$

Results of this study demonstrated by the aid of P. vulgarisa extracts revealed that this plant has antimicrobial activity against test organisms and this may be suggest the use of this extract in treatment of infectious diseases.

\section{REFERENCES}

[1] Maheshwari, P. and Kumar, A. "Antimicrobial activity of Abelmoschus moschatus leaf extracts". Curr. Tren. in Biotech. and Pharm. 3 (3), 2009, 260 - 266.

[2] Coates, A.; Hu,Y.; Bax, R.and Page, C. "The future challenges facing the development of a new antimicrobial drugs". Nat. Rev. Drug Discov. 1, 2002, 895-910.

[3] Recio, M.C. "A review of some antimicrobial compounds isolated from medicinal plants reported in the literature". Phytother. Res., 3, 1989, 117-125

[4] Cowan, M. M." Plant products as antimicrobial agents. Clin. Microbiol". Rev.12, 1999, 564582.

[5] Ebena, R. V.; Madunaju, R. E.; Ekpe, E. D. and Itugu, I. "Microbiological exploitation of Cardiac-glycosides and alkaloid from Garcina kola, Bonveria ocymoides, Kola nitida and Citrus aurantifolia". J. Appl. Bacteriol., 71, 1991, 398 - 401.

[6] Psotova J, Kolar M, Sousek J, Svagera Z, Vicar J, Ulrichova J. Biological activities of Prunella vulgaris extract. Phytother Res 2003; 17(9):1082-1087.

[7] Lamaison JL, Petitjean-Freyet C, Carnat A. Medicinal Lamiaceae with antioxidant properties, a potential source of rosmarinic acid. Pharm Acta Helv 1991; 66(7):185-188.

[8] $\mathrm{Xu} \mathrm{HX,} \mathrm{Lee} \mathrm{SF,} \mathrm{White} \mathrm{RL,} \mathrm{Bla} \mathrm{J.} \mathrm{Isolation} \mathrm{and} \mathrm{characterisation} \mathrm{of} \mathrm{an} \mathrm{anti-VSV}$ polysaccharide from Prunella vulgaris. Antiviral Res 1999; 44(1):43-54.

[9] Ryu SY, Lee CK, Lee CO, Kim HS, ZeeOP. Antiviral triterpenes from Prunella vulgaris. Arch Pharm Res1992; 15(3):242-245.

[10] Fang X, Yu MM, Yuen WH, Zee SY, Chang RC. Immune modulatory effects of Prunella vulgaris L on monocytes/macrophages. Int J Mol Med 2005; 16(6):1109-1116

[11] Trease,G.E. and Evans W.C. Pharmacology. 15thg Edn. Saunders Publishers, London, 2002, pp :42-393.

[12] Ogundipe, O.O., J.O. Moody, T.O. Fakeye and O.B. Ladip, "Antimicrobial activity of Mallotus oppositifolium extractives". Afr. J. Med. Med. Sci. Vol. 29: 3/4, 2000, pp 281-283.

[13] Kudi, A.C., Umoh, J.U., Eduvic, L.O.and Getu, J. "Screening of some Nigerian Medicinal plants for Antibacterial Activity". J. Ethanopharm. 67,1999,225-228.

[14] Reuben, K.D; Abdulrahman, F.I.; Akan, J.C.; Usman, H.; Sodipo, O.A. and Egwu, G.O. "Phytochemical Screening and In Vitro Antimicrobial Investigation of the Methanolic Extract of 
Vol. 06, No. 04; 2021

ISSN: 2456-8643

Croton Zambesicus Muell ARG'. Stem Bark. European Journal of Scientific Research, 23(1), 2008,134-140.

[15] Usman, H., F.I. Abdulrahman and A.H. Ladan. "Phytochemical and Antimicrobial Evaluation of Tribulus terrestris L. (Zygophylaceae) Growing in Nigeria". Res. J. Bio. Sci. Medwell Journals, 2(3),2007, 244-247.

[16] Franz,C.M., Du Toit,M., von Holy, A., Schillinger, U.and Holzapfel, W. H. "Production of nisinlike bacteriocins by lactococcus lactis strains isolated from vegetables". J Basic Microbiol; 37, 1997, 187-196.

[17] Doughari, J. H., Pukuma, M. S. and De, N. "Antibacterial effects of Balanites aegyptiaca L. Drel and Moringa oleifera Lam. on Salmonella typhi".African Journal of Biotechnology Vol. 6 (19), 2007, pp. 221

[18] Beyenbach, K. W. "Transport of magnesium across biological membranes. Magnes". Trace Elem.9,1990, $233-254$

[19] Singh, R.G. and Chauhan, S.M. "Anthraquinones and other biologically active compounds from the genus Rubia". Chem.Biodivers. 1(9), 2004,1241-1264

[20] Lu, Y.; Liu, R.; Sun, C. and Pan, Y. "An effective high-speed countercurrent chromatographic method for preparative isolation and purification of mollugin directly from the ethanol extract of the Chinese medicinal plant Rubia cordifolia". J. Sep. Sci. 30(9), 2007,13131317.

[21] Yizhoug, C.; Mei, S.; Sie, X. and Harold, C. "Antioxidant phenolic constituents in roots of Rheum officinale and Rubia cordifolia: structure-radical scavenging activity relationships". J. Agric. Food. Chem. 52(26), 2004,7884-7890.

[22] Kumar, V.P.; Chauhan, N.S. and Rajani, H.P.M. "Search for antibacterial and antifungal agents from selected Indian medicinal plants". J. Ethnopharm. 107, 2006, 182-188.

[23] Mahasneh, A.M. "Screening of some indigenous Qatari medicinal plants for antimicrobial activity". Phytother. Res.16, 2002, 751-753.

[24] Rios, J. L. and Recio, M.C. "Medicinal plants and antimicrobial activity". J. Ethnopharm.

$100,2005,80-84$.

[25] Vattem, D.A.; Mihalik, K.; Crixell, S.H.; McClean, R.J.C. "Dietary phytochemicals as quorum sensing inhibitors". Fitoterapia, 78, 2007, 302-310.

[26] Al-Fatimi, M.; Wurster, M.; Shroder, G.; Lindequist, U. "Antioxidant, antimicrobial, and cytotoxic activities of selected medicinal plants from Yemen". J. Ethnopharmacol., 111,2007, 657-666. 
Vol. 06, No. 04; 2021

ISSN: 2456-8643

[27] Aysegul, G., Mustafa, D. Metin, D. and Selahattin S. " The Biological Activity of Dyer,s Madder (Rubia tinctorium), Proceeding of ICDG, 2002, pp: 255-258

[28] Reema,H.and Adel, M. M. "Microbial Growth and Quorum Sensing Antagonist Activities of Herbal Plants Extracts". Molecules, 14,2009,3425-3435.

[29] Kalyoncu, F.; Cetin, B. and Saglam,H. "Antimicrobial activity of common madder (Prunella vulgarisa L.). Phytother. Res. 20(6),2006,490-942.

[30] Tadeg, H.; Mohammad, E.; Asres, K.; Gebre-Mariam, T. "Antimicrobial activities of some selected traditional Ethiopian medicinal plants used in the treatment of skin disorders". J.Ethnopharmacol. 100, 2005,168-175.

[31] Biswas, T.K., Maity, L.N. and Mukherjee, B. "Wound healing potential of Pterocarpus santalinus linn: A pharmacological evaluation". Intl. J. low, 3 (3), 2004,143-150.

[32] Suleyman, B. and Huseyin,H. "Studies on the Ecology of Chrozophora tinctoria L. and Prunella vulgarisa L. in Western Anatolia ".Tr. J. of Botany,23,1999,33-40.

[33] Sedigheh, S.; Zoheir, Y.A.; Yaghobi Ashrafi,. Fakhr,T. and Hassan, M. A. "Study Methods of Dormancy Breaking and Germination of Common Madder (Prunella vulgarisa L. ) Seed in Laboratory Conditions ".Bota. Res. Inter., 2(1),2009,07-10. 